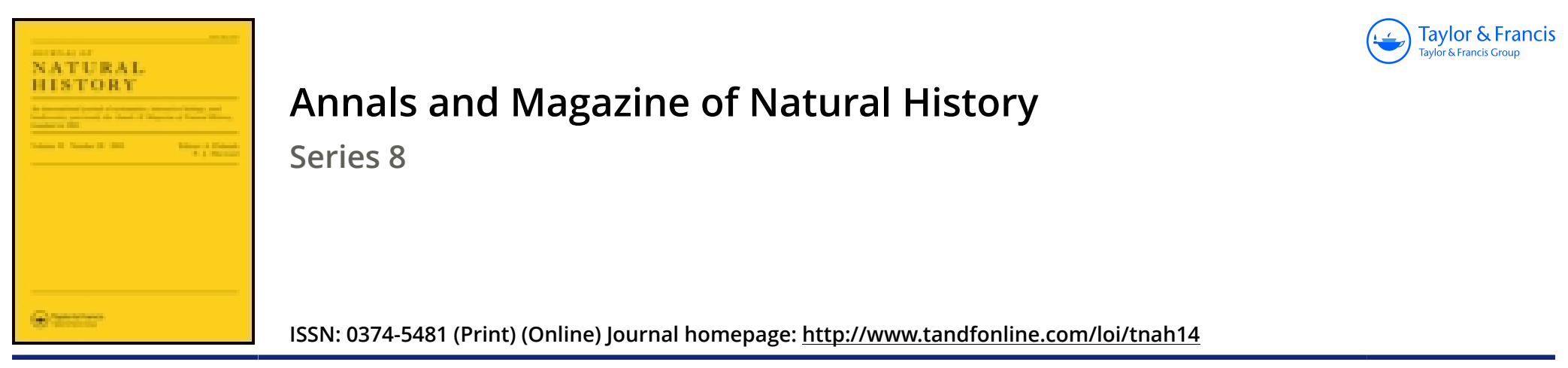

\title{
XIV.-Descriptions of new genera and species of Noctuidæ
}

\section{Sir George F. Hampson Bart F.Z.S.}

To cite this article: Sir George F. Hampson Bart F.Z.S. (1914) XIV.-Descriptions of new genera and species of Noctuidæ, Annals and Magazine of Natural History, 13:73, 146-175, DOI: 10.1080/00222931408693462

To link to this article: http://dx.doi.org/10.1080/00222931408693462

曲 Published online: 15 Sep 2009.

Submit your article to this journal $₫$

Џll Article views: 3

Q View related articles $๘$ 
punctured; scutellum slightly bigibbous, with small wellseparated punctures on a shining surface; base of metathorax of the same type as that of $P$. noachinus. Legs with much dark hair, covering outer side of middle and hind tibix and tarsi; brush at apex of hind basitarsi dark; tegulæ black. Wings dusky, very strongly so apically; stigma and nervures piceous; second s.m. very broad, receiving first r. $n$. well before its end. Abdomen shining, the first two segments finely punctured, the first more closely than the second; hair at apex black; of venter, to end of fourth segment, glistening silvery; second ventral segment with a very large tubercle, the posterior slope of which is beset with silvery hairs.

Hab. Purnong (S.W. Fulton; Nat. Mus. Victoria, 138).

Andrena bateice, Cockerell.

Antrena batesice, Cockerell, Trans. Am. Ent. Soc. xxxvi. p. 248. Oyprus.

Following, I believe, an erroneous label, I wrote batesia, and the collector's name Miss Bates, although $I$ ought to have known better, being well aware of the brilliant work of Miss Dorothea Bate in Cyprus.

Coelioxys ducalis, Smith.

Professor C. F. Baker sends me this fine species, collected by himsolf at Los Baños, Philippine Islands. At the same losality he has also taken both sexes of C. philippensis, Bingham.

Xylocopa morio callichlora, Cockerell, variety $a$.

Apical half of anterior wings suffused with coppery red. Three females; Guayaquil, Ecuador, May to June, 1913 (C. T. Brues). X. callichlora probably deserves to rank as a distinct species.

$\mathrm{X} I \mathrm{~V} .-$ Descriptions of new Genera and Species of Noctuidæ. By Sir George F. Hampson, Bart., F.Z.S.

[Continued from vol. xii. p. 601.]

\section{CUCULLTANA.}

2122 b. Cucullia nubipicta, sp. n.

万. Head and thorax blue-grey mixed with fuscous brown; tegula with two dark lines at middle and one near tips; palpi with blackish streaks at sides except towards tip; pectus whitish tinged with red-brown; abdomen grey tinged 
with dark brown, the ventral surface whitish tinged with red-brown. Fore wing blue-grey irrorated with blackish; a slight blackish streak on costa towards base; antemedial line blackish, diffused to submedian fold, then slight, strongly angled inwards on vein 1 and outwards above inner margin, the inner area beyond it tinged with fuscous; a slight black point in upper part of middle of cell; reniform hardly traceable, with slight black streak above and minute black points on inner and outer sides above, a small black spot above it on costa with the indistinct dark postmedial line arising from it, strongly bent outwards below costa, then waved, very oblique below vein 4 and angled inwards in submedian fold to near the antemedial line, then outwards at vein 1 ; the costal area tinged with fuscous towards apex; subterminal line very indistinct, dark, incurved below vein 4, some dark suffusion beyond it at discal fold and below vein 2 ; a terminal series of black strix. Hind wing semihyaline white, the veins tinged with brown especially towards termen; the underside with the costa irrorated with brown except towards base.

Hab. Br. E. Africa, Aberdare Mts., 8000' (Neave), 1 హ type. Exp. $44 \mathrm{~mm}$.

\section{8 b. Callierges peruviana, sp. $\mathrm{n}$.}

Antennæ of male with the apical part simple ; the branches long on inner side, veiy short on outer.

$\delta$. Head white and dark brown; antennæ dark brown; thorax blue-grey mixed with dark brown, the tegulæe with white line near tips, which are black-brown; tarsi blackbrown ringed with white; abdomen grey dorsally suffused with dark reddish brown, ventrally irrorated with brown. Fore wing blue-grey irrorated with dark brown and striated with black, the medial area suffased with dark brown extending obliquely to costa near apex ; a curved black streak below base of cell; antemedial line absent; claviform large, defined by black; orbicular grey irrorated with brown and defined by black except above, extending to below the cell; reniform grey irrorated with brown and defined by black except on upper part of outer side, rather rounded; postmedial line black, oblique to vein 6 , then inwardly oblique, strongly dentate and incurved in submedian interspace to near the claviform; subterminal line represented by a dark shade between veins 7 and 4 and an oblique black streak from above vein 2 to submedian fold; a fine dark line expanding into spots at the interspaces; a fine white line at base of cilia. Hind wing white, the marginal areas suffused wich reddish brown, the veins black-brown; a small black $10^{*}$ 
discoidal spot; cilia with a brown line through them; the underside with the costal area irrorated with brown, a postmedial series of short black streaks on the veins. $34 \mathrm{~mm}$.

Hab. Peru, Acopampa (Watkins), 1 o type. Exp.

\section{8 a. Derthisa hamapasta, sp. n.}

o. Head and thorax ochreous white faintly tinged with rufous, the metathorax rufous at extremity; antennæ brownish; palpi brown at base; abdomen ochreous white tinged with brown, the anal tuft rufous. Fore wing ochreous white tinged with rufous; the basal area suffused with blood-red and with a slight dark streak above inner margin ; subbasal line represented by black striæ from costa and cell; antemedial line blackish, obliquely excurved and slightly sinuous; the cell and area before the postmedial line from costa to vein 2 suffused with blood-red ; orbicular and reniform ochreous white with some blood-red in centres, defined at sides by blackish, the former rounded and conjoined to a similar spot on and below median nervure, the latter constricted at middle and extending to well below the cell; postmedial line blackish, oblique to vein 7 , then somewhat dentate, slightly incurved at discal fold and strongly below vein 3 ; subterminal line whitish, defined on inner side by blood-red towards costa, excurved below vein 7 and at middle, incurved and slightly waved below vein 4 ; a terminal series of small dark brown lunules; cilia dark brown at tips. Hind wing uniform ochreous white.

Hah. 'T'ripoli, Cyrene (Sladden), 1 o type. Exp. $36 \mathrm{~mm}$.

\section{8 a. Amathes tripolensis, sp. n.}

$\delta$. Head and thorax purplish red-brown mixed with some grey; palpi and sides of frons black-brown; pectus except in trons and hind legs whitish tinged with red-brown; abdomen whitish suffused with ochreous brown. Fore wing bright purplish red-brown slightly irrorated with dark scales ; antemedial line slight, dark, excurved below costa, then indistinctly double filled in with whitish and obliquely excurved; orbicular an oblique dark bar; reniform a blackish-brown lunule; postmedial line indistinctly double, dark filled in with whitish, somewhat excurved to vein 4 , then incurved; subterminal line represented by a series of minute dark spots in the interspaces, slightly excurved below vein 7 ; a terminal series of small dark spots. Hind wing white faintly tinged with brown; a snall blackish discoidal spot, diffused dark 
subterminal line and slight terminal line; the underside with the costal area tinged with red-brown, some dark points on termen towards apex.

Hab. Tripou, Cyrene (Sladden), 1 ठั type. Exp. $38 \mathrm{~mm}$.

\section{ACRONTETINA.}

\section{7 a. Trachea normalis, sp. $\mathrm{n}$.}

$\delta$. Head and thorax pale reddish brown mixed with fuscous; tarsi blackish ringed with white; abdomen ochreous tinged with brown. Fore wing ochreous thickly irrorated with brown and blackish; subbasal line represented by double black striæ from costa and cell, some black beyond it below the costa; antemedial line black defined on inner side by ochreous, curved, waved; claviform defined by rather diff'used black, short; orbicular and reniform defined by black, the former round, the latter open above and with slight black streaks beyond it above and below vein 6; medial line represented by a small black spot on the costa and diffused line from lower angle of cell to inner margin; postmedial line black, double at costa, bent outwards below costa, then dentate, incurved below vein 4 , the costa beyond it blackish with some pale points; subterminal line blackish, slightly angled outwards at vein 7 and excurved at veins 4, 3 ; a terminal series of small black lunules; cilia with a black line at middle. Hind wing white, the termen tinged with brown; a dark terminal line; cilia white mixed with brown; the underside with the costal and terminal areas irrorated with brown, a small blackish discoidal spot and postmedial line excurved below the costa.

Hab. Thansvaal, Pretoria (Zutrencka), 1 d type. Exp. $38 \mathrm{~mm}$.

\section{6a. Trachea leucura, sp. $\mathrm{n}$.}

Abdomen of male with very large white genital tufts; both wings on underside slightly clothed with ferruginous hair and scales to beyond middle.

$\delta$. Head, thorax, and abdomen cupreous red-brown, the last with very large white genital tuft of hair ; tarsi dark brown ringed with white. Fore wing cupreous red-brown; a white point at base of cell and small subbasal spots below costa and cell, the lower with a dark streak beyond it in submedian fold to below origin of vein 2 ; small antemedial white spots below costa and in submedian fold; orbicular represented by three white points with a dark streak beyond them to the reniform, which is defined by seven white points; 
a small white spot on costa above end of cell with some points beyond it ; a small postmedial spot on inner margin; small subterminal white spots below costa, on vein 4 and above tornus with white points on slight dark marks between them; a fine terminal dark line with white points at the veins and a fine white line at base of cilia. Hind wing pale cupreous brown; a fine dark terminal line and whitish line at base of cilia. Underside of both wings with the basal half suffused with rufous; fore wing with dark postmedial line slightly excurved at middle; hind wing with dark discoidal lunule, postmedial line and traces of subterminal line towards costa. $36 \mathrm{~mm}$.

Hab. Goud Coast, Bibianaha (Spurrell), 1 t type. Exp.

\section{8 a. Trachea phonicolopha, sp. n.}

б. Head and thorax red-brown, the prothoracic crest with some white at tips, the patagia with some white scales; antennæ blackish; pectus and legs rufous, the tarsi blackish ringed with white; abdomen bright rufous with some whitish at base, the lateral tufts from base of abdomen deep purplered. Fore wing bright red-brown suffused in parts with dark brown; a small tuft of white scales at base of vein 1 ; subbasal line double, black filled in with pure white, waved, from costa to vein 1 ; antemedial line indistinct, double, dark, waved, with small pure white spots on it at and below costa, in submedian fold, and on vein 1; orbicular with white spot at middle and four white spots defined by blackish at its angles; reniform with white spot in upper part, irregular spot in lower part, lunule at middle of outer edge, and seven small white spots in its circumference, all defined by blackish; postmedial line indistinctly double, dark, filled in with white at and below costa and towards inner margin, bent outwards below costa, then slightly waved, incurved at discal fold and oblique below vein 4, some white points beyond it on costa; subterminal line with a bifid white spot at costa, then represented by a series of minute white spots defined on inner side by dentate blackish marks, oblique below vein 3 ; a fine black terminal line with white points at the veins. Hind wing whitish suffused with red-brown, especially on terminal area ; a fine dark terminal line; the underside whiter, a dark discoidal lunule, crenulate postmedial line from costa to vein 2, and dark subterminal shade from costa to vein 4 .

Hab. Lurenzo Marques, 1 t type. Exp. $36 \mathrm{~mm}$. 


\section{5 a. Perigea gypsina, sp. n.}

q. Head and tegulæ rufous mixed with whitish, the latter with slight rufous medial line and blackish tips; antennæ ringed brown and whitish towards base; thorax and abdomen white; legs suffused with rufous, the fore tarsi blackish with pale rings. Fore wing white ; some pale rufous on base of costa and below the cell; an oblique wedge-shaped rufous antemedial patch from costa to median nervure with traces of an oblique sinuous line front it to inner margin ; orbicular and reniform represented by confluent white patches, the former with curved rufous mark below it and rufous above it on costa; a rufous striga defined on each side by white from middle of costa; an oblique wedge-shaped postmedial patch from costa to vein 2 , above which it is connected with the termen by a diffused fascia; postmedial line indistinct and dark on the rufous area, then almost obsolete, bent outwards below costa, then dentate and produced to a double series of blackish points with whitish points between them, some white points beyond it on costa; an oblique wedge-shaped rufous patch from termen below apex and a terminal series of black points. Hind wing white suffused with brown except at base and on inner area, darker towards termen; a terminal series of blackish strix defined on inner side by white; cilia white, brown towards apex ; the underside white, the costal area and terminal area to vein 2 irrorated with pale rufous, a bright rufous apical patch and terminal series of small black lunules from apex to vein 2. $40 \mathrm{~mm}$.

Hab. Gold Const, Kumasi (Sanders), 1 q type. Exp.

\section{1 a. Perigea cupricolora, sp. n.}

$\delta$. Head and thorax cupreous red slightly mixed with blackish ; palpi with some black at side ; tarsi blackish with pale rings; abdomen grey-brown, the ventral surface redbrown. Fore wing cupreous red-brown, the base and costal half to the postmedial line with some fuscous suffusion, the veins with dark streaks; subbasal line represented by two dark striæ from costa; antemedial line very indistinct, double, waved; claviform a minute black spot; orbicular very faintly delined by brown; reniform very faintly defined by brown and some black points, irregular, extending to below the cell; an oblique sinuous line from lower angle of cell to inner margin; postmedial line dark, slightly waved, excurved to vein 4, then incurved, a series of minute black 
points beyond it on the veins; subterminal line blackish, waved, excurved below vein 7 and at middle; a fine black terminal line and pale line at base of cilia. Hind wing whitish suffused with brown especially on terminal area; cilia whitish tinged with rufous; the underside brownish white, the costal area suffused with rufous, a dark discoidal bar and postmedial line except on inner area.

Hab. Br. E. Africa, Nairobi (Anderson), 1 o type. Exp. $34 \mathrm{~mm}$.

\section{4 a. Perigea violascens, sp. $\mathrm{n}$.}

ㅇ. Head and thorax dark brown mixed with purple-grey; tarsi blackish with pale rings; abdomen grey suffused with fuscous brown, the crests blackish. Fore wing dark brown thickly irrorated with purple-grey and with a slight cupreous gloss; antemedial line blackish defined on inner side by grey, double at costa, sinuous, incurved at vein 1 ; orbicular and reniform with grey annuli, the former small, round, the latter figure-of-eight shaped; an indistinct sinuous dark medial line ; postmedial line blackish defined on outer side by grey, dentate and produced to short streaks on the veins, excurved to vein 4, then incurved, some white points beyond it on costa; subterminal line purple-grey defined on inner side by dark brown suffusion, excurved below vein 7 and at middle; a terminal series of grey points. Hind wing dark brown with a cupreous gloss; a terminal series of black striæ with whitish points at the veins ; the underside bluegrey thickly irrorated with brown, an indistinct diffused curred postmedial line from costa to vein 2 and faint subterminal shade.

Hab. C. China, Chungking ( $W . R . B r o w n), ~ 1 q$ type. Exp. $30 \mathrm{~mm}$.

\section{2 a. Oligia hypoxantha, sp. n.}

Mid and hind coxæ of male with large tufts of black-brown hair ; abdomen with tuft of reddish-ochreous hair on ventral surface towards extremity; wings on underside clothed with ochreous androconia to near termen.

Head and thorax red-brown mixed with ochreous white; palpi with the second joint whitish at extremity; abdomen brown mixed with ochreous white, the ventral surface ochreous. Fore wing dark red-brown mixed with pale ochreous ; antemedial line indistinct, double, brown filled in with ochreous, sinuous; orbicular and reniform with slight ochreous annuli defined by black, the former round ; an indistinct sinuous brown medial line; postmedial line indistinct, 
brown, bent outwards below costa, slightly incurved at discal fold and incurved below vein 4 ; subterminal line indistinct, brown, slightly excurved below vein 7 and at middle; a terminal series of dark points. Hind wing reddish brown. Underside of both wings clothed with ochreous androconia, the terminal areas brown mixed with whitish; fore wing with slight dark postmedial line excurved below costa; hind wing with black discoidal point.

Hab. Goud Const, Bibianaha (Spurrell), 1 of type; S. Nigeria, Olokemeji (Dudgeon), 1 б, 4 4 . Exp. 24-26 mm.

\section{2 b. Oligia atrivitta, sp. $\mathrm{n}$.}

Femora of male with tufts of hair ; fore wing with the retinaculum formed by a fringe of scales; hind wing on underside with the basal half of costal area and the cell thickly clothed with rufous scales.

$\delta$. Head reddish ochreous, the frons with blackish bars at middle and above; antennæ brown; palpi black-brown, whitish in front; thorax and abdomen black-brown, the tegulæe edged with reddish ochreous; pectus and legs reddish ochreous, the tufts of hair on femora black, the tibiæ and tarsi banded with blackish. Fore wing with the basal and postmedial areas reddish ochreous irrorated with brown, the antemedial, medial, and terminal areas dark brown; subbasal line blackish, curved, from costa to vein 1 ; antemedial line blackish, curved; orbicular with blackish outline, round; reniform an ill-defined ochreous patch exteuding to costa and defined by black on inner side; an oblique black patch from the cell below the orbicular to the postmedial line, which is indistinct, double, excurved and minutely waved to vein 2 where it is angled inwards, then oblique to inner margin, some blue-grey beyond it on inner area ; subterminal line only defined by the dark terminal area, excurved at vein $\gamma$ and middle; a black terminal line and fine pale line at base of cilia. Hind wing dark brown; some ochreous at base ; a fine pale line at base of cilia. Underside of fore wing with the fringe of scales on basal costal area bright rufous ; hind wing with the rough scales on costal area and in ceil bright rufous.

o. Fore wing with the basal and postmedial areas browner ; the underside without rufous.

Ab. 1. $q$. Fore wing with the basal and postmedial areas more prominently reddish ochreous, the patch on inner area beyond the postmedial line pale ochreous.

Hab. Gold Const, Bibianaha (Spurrell), $1 \delta, 2$ type. Exp. 16-20 mm. 


\section{4a. Eriopus argyrosema, sp. $\mathrm{n}$.}

i. Head and thorax bright rufous ; antennæ dark brown; pectus greyish; abdomen grey-brown, the basal crest rufous. Fore wing bright rufous ; two slight oblique whitish subbasal lines from costa to median nervure ; antemedial line almost medial, brown defined on inner side by whitish, inwardly oblique and almost straight; orbicular represented by a slight inwardly oblique whitish striga defined on outer side by dark brown; reniform an oblique silvery-white $Y$-shaped mark defined at sides by black; a faint diffused oblique brown line from lower angle of cell to inner margin ; postmedial line brown, oblique and faintly defined on outer side by whitish below vein 4, an indistinct diffused brown line beyond it; subterminal line silvery white defined on each side by dark brown and incurved from costa to below vein 5 and with traces of a fine waved white line beyond it, then obsolete. Hind wing grey-brown; cilia rufous at base, whitish at tips; the underside pale grey, the costal area suffused with rufous, a dark discoidal bar and postmedial line waved towards costa.

Hab. Peru, Chanchamayo, 1 \& type. Exp. $26 \mathrm{~mm}$.

\section{9 a. Eriopus pyrocauta, sp. n.}

9. Head and thorax red-brown suffused with grey-white; antennæ dark brown; tarsi brown ringed with white; abdomen pale grey-brown, the crest on third segment fiery red. Fore wing red-brown suffused with fiery red and slightly irrorated with whitish, the terminal area tinged with bluegrey; antemedial line very indistinct, whitish, excurved to submedian fold and angled inwards at vein 1 ; minute white spots in middle of cell and at lower angle; postmedial line indistinct, whitish faintly defimed on each side by brown, oblique to vein 4 , then iuwardly oblique, some minute white points beyond it on costa; a very slight oblique somewhat sinuous bluish-white subterminal line from vein 4 to inncr margin; a fine white line at base of cilia. Hind wing red-brown, the inner area fiery red; a fine white line at base of cilia; the underside bluish white suffused with brown.

Hab. Fr. Guiana, St. Laurent Maroni, 1 o type. Exp. $18 \mathrm{~mm}$.

$$
\text { 3492 a. Chytonyx albiplaga, sp. n. }
$$

$\delta$. Head and thorax fuscous brown mixed with white and some ochreous; tarsi ringed with white; abdomen ochreous 
mixed with fuscous brown, the crests black at tips. Fore wing reddish ochreous suffused with fuscous brown, the inner half of medial area white from just above median nervure; traces of a double dark sinuous subbasal line from costa to submedian fold; antemedial line very indistinct, dark, excurved below costa aud angled inwards at vein 1; orbicular large, rather triangular, white, conjoined to the white inner area; reniform with obscure ochreous annulus, its centre defined by fuscous brown; postmedial line indistinct, dark, minutely dentate, excurved from below costa to vein 4, then incurved, and oblique from vein 3 to inner margin towards tornus; faint traces of a minutely waved dark subterminal line; a terminal series of minute blackish spots. Hind wing ochreous whitish tinged with brown, the veins and terminal area rather darker; a diffused dark discoidal spot; cilia whitish; the underside ochreous whitish slightly irrorated with brown, a large blackish discoidal spot, traces of a waved postmedial line and a black terminal line lunulate on costal half.

Hab. Formosa (Elwes), 1 ô type. Exp. $32 \mathrm{~mm}$.

\section{5 a. Bryophila fulvisparsa, sp. $\mathbf{n}$.}

o. Head, thorax, and abdomen white mixed with black and some fulvous; antennæ black; palpi black at sides except towards tips; pectus and legs white mixed with brown, the tarsi black ringed with white; ventral surface of abdomen white with slight blackish segmental lines towards extrenity. Fore wing grey-white thickly irrorated with blackish and some fulvous, the ante- and postmedial areas with more fulvous; the basal costal area with some black suffusion defined by the indistinct sinuous subbasal line from costa to submedian fold; antemedial line black defined on inner side by whitish, sinuous; orbicular and reniform with whitish annuli, the former small, round, the latter indistinet; postmedial line black defined on outer side by whitish, waved, excurved from costa to vein 3 , then strongly incurved, some whitish points beyond it on costa; traces of a sinuous dark subterminal line excurved below vein 7 and at middle; a terminal series of black striæ; cilia chequered dark and white. Hind wing white irrorated with tuscous brown; a small fuscous discoidal spot, obliquely curved postmedial line, and faint diffused subterminal shade; the underside with blackish discoidal lunule and waved curved postmedial line. $30 \mathrm{~mm}$. 


\section{7 a. Bryophila ancemica, sp. $\mathrm{n}$.}

$\delta$. Head and thorax white tinged with brown and irrorated with a few blackish scales; antennæ blackish; palpi with some black at side of second joint; tarsi black ringed with white; abdomen white tinged with fuscous, the crests blackish. Fore wing white tinged with brown and in parts with yellowish and slightly irrorated with blackish; a black streak below submedian fold from base to the antemedial line and between the ante- and postmedial lines; a slight blackish subbasal streak in the cell; antemedial line indistinct, blackish, angled outwards below the costa and submedian fold and inwards below the cell and at vein 1 ; orbicular and reniform small brownish spots with faint whitish annuli; postmedial line very indistinct, blackish, bent outwards below costa and oblique from vein 4 to submedian fold; traces of an oblique subterminal line with short black streaks beyond it above and below vein 5 and below vein 2 ; a terminal series of minute black spots; cilia with series of blackish spots at middle and tips. Hind wing white tinged with reddish brown; cilia white with a brownish line near base; the underside with slight brownish discoidal spot and sinuous postmedial line excurved below the costa.

Hab. Algeria, Batna (Eaton), 1 ơ type. Exp. $2 € \mathrm{~mm}$.

\section{0 a. Acronycta lilacina, sp. n.}

q. Head and thorax purple-grey mixed with dark brown; palpi with the first and second joints black except at tips; tarsi dark brown with pale rings ; abdomen grey suffused with brown. Fore wing purple-grey mixed with dark brown; an indistinct curved blackish subbasal line from costa to median nervure ; a black streak in submedian fold from base to the antemedial line towards which it forks; antemedial line dark, indistinct except at costa, oblique, sinuous, angled inwards below the cell and slightly at vein 1 ; some rufous beyond it below the cell; orbicular and reniform absent; a black streak above terminal part of median nervure to just beyoud the cell, with a slight streak below its extremity and some diffused rufous beyond the cell; a dark shade from costa to upper angle of cell; postmedial line black defined on inner side by pale grey, dentate, strongly excurved below costa, angled inwards at discal fold and strongly in submedian fold, some white points beyond it on costa and a wedge-shaped dark shade from before it to termen in submedian fold; a terminal series of lunulate blackish spots; 
eilia whitish mixed with brown. Hind wing whitish suffused with brown; cilia whitish with a blackish line through them; the underside grey irrorated with dark brown, a slight dark discoidal spot, rather diffused waved postmedial line indistinct except towards costa, and faint subterminal shade.

Hab. C. China, Chungking (W. R. Brown), 1 ㅇ type. Exp. $30 \mathrm{~mm}$.

3880 a. Lophotarsia minuta, sp. n.

Head and thorax grey-brown; antennæ blackish; tarsi black ringed with white; abdomen grey-brown suffused with black, the anal tuft ochreous. Fore wing reddish brown suffused with fuscous and irrorated with grey; traces of a curved dark antemedial line; the orbicular and reniform represented by some grey scales; faint traces of a curved postmedial line; subterminal line represented by some minute blackish streaks in the interspaces; a terminal series of black points. Hind wing pure white, the costa tinged with brown towards apex; the underside with the costal area irrorated with brown, a terminal series of dark points except towards tornus. $20 \mathrm{~mm}$.

Hab. N. Nigeria, Minna (Macfie), 1 ơ, 1 q type. Exp.

3913 a. Amphidrina melanosema, sp. n.

․ Head and thorax white tinged with rufous; palpi pale rufous with some blackish at sides; legs pale rufous, the fore tibiæ black, the tarsi black with pale rings; abdomen greyish tinged with rufous and irrorated with blackish. Fore wing pale purplish grey tinged in parts with rufous and irrorated with blackish; antemedial line indistinct, double, blackish, oblique and slightly sinuous; orbicular a minute black spot defined by whitish ; reniform black with whitish annulus, produced at lower extremity, a blackish patch above it on costa ; postmedial line double, hlack filled in with whitish, oblique to vein 6 and slightly incurved below vein 4 ; a terminal series of minute black lunules. Hind wing fuscous brown with a cupreous gloss; cilia whitish tinged with brown; the underside grey-white irrorated with blackish, a small black discoidal spot and curved postmedial line.

Hab. Lorenzo Marques, 1 type. Exp. $34 \mathrm{~mm}$.

3933 a. Athetis atrispherica, sp. n.

ð. Head and thorax red-brown; antennæ with dark rings ; palpi black at sides except at tips; tarsi black ringed 
with white; abdomen grey suffused with dark brown. Fore wing glossy red-brown tinged with grey and with slight dark irroration; subbasal line indistinetly double, blackish, from costa to submedian fold, antemedial line double, blackish, slightly angled outwards at subcostal nervure, then sinuous; orbicular a black point with whitish annulus; reniform oblique elliptical, velvety black with slight whitish annulus; a sinuous blackish medial line; postmedial line black, excurved from below costa to vein 4 , then incurved, a series of black points beyond it on the veins and some pale points on the costa; subterminal line blackish slightly defined on outer side by whitish, somewhat excurved below vein 7 ; a terminal series of black points and a fine whitish line at base of cilia. Hind wing reddish brown; a small blackish discoidal spot; a fine pale line at base of cilia; the underside whitish tinged and irrorated with brown, a small discoidal spot and rather diffused curved postmedial line.

Hab. Br. E. Arrica, Nairobi (Andersun), 2 to type. Exp. $32 \mathrm{~mm}$.

3992. Athetis melanopis, Hmpsn., nec 3917. Rename A. melanosema.

\section{4a. Monodes discisigna, sp. $\mathrm{n}$.}

$\delta$. Head and thorax ochreous mixed with brown; antennæ ringed with blackish; palpi with some black at sides; fore and mid tibiæ and tarsi streaked with black; abdomen ochreous suffused with brown, the basal crest black at tip, the anal tuft rufous. Fore wing ochreous suffused in parts with rufous and irrorated with blackish, the area beyond the cell suffused with darker brown between veins 5 and 2 ; the interspaces of terminal area with slight dark streaks except towards apex and tornus; subbasal line represented by two blackish strix from costa and two black points below the cell; antemedial line represented by a blackish striga from costa and small black spot below origin of vein 2 ; the terminal part of median nervure streaked with white; a diffused black-brown spot in middle of cell and round blackish patch beyond the cell ; postmedial line represented by a series of blackish points, oblique to the patch beyond the cell, then incurved and with small black spot below vein 2 , some slight black streaks beyond it on costa; subterminal line represented by a series of minute blackish spots, excurved below vein 7 , then oblique; a terminal series of black points ; cilia with series of blackish points at middle and tips. Hind wing white tinged with red-brown especially 
on apical part of terminal area; the underside with the costal and terminal areas irrorated with brown.

Hab. Jamaica, Cinchona (Kaye), 1 o type. Exp. $28 \mathrm{~mm}$.

\section{1 a. Monodes streptisema, sp. n.}

๙. Head, thorax, and abdomen yellow mixed with pale red-brown; antennæ blackish; palpi blackish with the extremities of the second and third joints white; tarsi ringed with white; abdomen with some white at base of dorsum. Fore wing yellow mixed with red-brown; subbasal line white detined at sides by black scales, angled inwards at median nervure and ending at vein 1 ; an oblique blackish shade from submedian fold to inner margin before the antemedial line, which is white defined at sides by some black scales, angled outwards below costa and submedian fold and inwards in the cell; orbicular white defined by black, small, round; reniform defined by black except above, its upper lart yellowish, its lower part white, constricted at middle ; postmedial line white defined at sides by red-brown, forming a small spot at costa, bent outwards below the costa and touching the upper part of reniform, then minutely waved, some white points beyond it on the costa; subterminal line yellowish defined on each side by diffused red-brown, forming an oblique bar from costa to discal fold where it is interrupted, then forming an almost terminal band; a terminal series of black points. Hind wing red-brown with a cupreous gloss ; cilia whitish with a red-brown line through them; the underside whitish irrorated with brown especially on costal area, a small brown discoidal spot and postmedial line slightly waved towards costa.

Hab. N.E. Peru, Huancabamba, Cerro del Pasco, $1 \delta$ type. Exp. $20 \mathrm{~mm}$.

Type, $N$. albilinea.

Genus Nanamonodes, nov.

Proboscis fully developed; palpi upturned, the second joint reaching to vertex of head and moderately scaled, the third short; frons smooth; eyes large, round; antennæ of male ciliated ; huild slender; thorax clothed almost entirely with scales and without crests; tibiæ smoothly scaled; abdomen with dorsal crests on basal segments. Fore wing rather long and narrow, the apex rounded, the termen evenly curved and not crenulate; veins 3 and 5 from near angle of cell; 6 from npper angle ; 7 and 9 absent ; 10,11 from cell. Hind wing wilh veins 3,4 coincident; 5 obsolescent from middle of discocellulars; 6,7 from upper angle of cell ; 8 arastomosing with the cell near base only. 


\section{7 a. Nanamonodes albilinea, sp. n.}

ส. Head and thorax brown mixed with grey-white; palpi blackish; tarsi blackish with pale rings; abdomen fuscons brown, the anal tuft whitish, the ventral surface grey. Fore wing grey suffused with brown and irrorated with blackish especially on basal and terminal areas; antemedial line white defined by black scales, almost medial, curved; a black spot at lower angle of cell touching the postmedial line which is white defined by black scales, oblique to discal fold, then inwardly oblique; a dark subterminal shade and a terminal series of minute black spots. Hind wing greyish brown; the underside whitish tinged with brown.

Hab. Venezuela, 1 of type. Eap. 14 mm.

\section{0 a. Calymniodes pygmea, sp. $\mathrm{n}$.}

q. Head and thorax pale rufons; antennæ dark brown; abdomen grey-brown. Fore wing yellowish suffused with fiery red and slightly irrorated with blackish scales, the postmedial area brownish white shading to brown before the subterminal line; antemedial line whitish defined on outer side by brown, oblique; curving round at inner margin and meeting the postmedial line, which is white defined on inner side by brown and almost evenly excurved; subterminal line whitish defined on inner side by rather diffused brown, angled outwards at vein 6 and excurved at middle. Hind wing grey-brown; cilia with a fine white line at base ; the underside whitish suffused with brown especially on terminal area, a dark discoidal spot, and indistinct diffused curved postmedial line. $26 \mathrm{~mm}$.

Hab. Fr. Gulana, St. Laurent Maroni, $1 q$ type. Exp.

4531 a. Closteromorpha cupreiplaga, sp. $n$.

Closteromorpha reniplaga, Hmpsn. Cat. Lep. Phal. B.M. ix. p. 177, $q$ (nec $0^{*}$ ).

Head, thorax, and abdomen ochreous suffused with bright rufous. Fore wing leaden-grey tinged with rufous, the basal area suffused with rufous except at inner margin; antemedial line very indistinct, blackish, slightly curved inwards to costa ard excurved at inner margin; a large cupreous rufous patch faintly defined by blackish, extending on costa from end of cell to apex and down to vein 3 , its outer edge excised; traces of a dark incurved postmedial line from the patch to inner margin; a terminal series of 
slight blackish lunules and more prominent spot at submedian fold. Hind wing brown with a cupreous-red tinge. Underside of both wings brownish with a cupreous-red tinge.

Hab. Br. Guinna, Demerara (Rodway), 1 o type ; Fr. Guina, St. Laurent Maroni, $\delta$ in U.S. Nat. Mus. Exp. $34 \mathrm{~mm}$.

\section{6 a. Calymnia monotona, sp. $\mathrm{n}$.}

q. Head and thorax reddish brown mixed with grey; antennæ blackish with slight pale rings; palpi blackish; tarsi blackish ringed with white; abdomen blackish brown. Fore wing grey tinged with red-brown and thickly irrorated with dark brown; subbasal line blackish, sinuous, from costa to submedian fold; antemedial line blackish defined on inner side by grey, oblique towards costa, then slightly sinuous; a faint curved dark medial shade; postmedial line blackish defined on outer side by grey, excurved to vein 6 , then slightly sinuous, some slight dark streaks and pale striæ beyond it on costa; subterminal line grey defined on inner side by rather diffused blackish, very slightly excurved at vein 7 and incurved at submedian fold; a terminal series of black striæ and fine pale line at base of cilia. Hind wing pale reddish brown; a terminal series of slight blackish strix and slight pale line at base of cilia; the underside whitish thickly irrorated with brown, a small discoidal spot and rather diffused curved postmedial line.

Hab. Br. E. Africa, Nairobi (Anderson), 1 \& type. Exp. $32 \mathrm{~mm}$.

\section{4a. Busseola hemiphlebia, sp. n.}

§. Head and thorax red-brown mixed with blackish; palpi and legs black-brown, the tarsi ringed with white; abdomen greyish brown. Fore wing pale reddish brown irrorated with fuscous; a darker fascia along median nervure expanding beyond the cell to termen below apex and tornus; the veins of costal half with fine grey streaks; a slight black streak in basal half of submedian fold; white points defined by a few black scales in and beyond lower angle of cell; a curved postmedial series of slight black points; an oblique subterminal series of slight blackish marks in the interspaces from below vein 7 to above 3 ; a terminal series of black points. Hind wing brown with a cupreous gloss; a fine dark terminal line; cilia whitish tinged with brown; the underside whitish suffused with brown, the costal area darker.

Hab. N. NigerIa, Kateregi (Macfie), 1 ơ type. Exp. $26 \mathrm{~mm}$.

Ann. \& Mag. N. Hist. Ser. 8. Vol. xiii. 
4675 a. Busseola mesophea, sp. $\mathrm{n}$.

Head, thorax, and abdomen pale brown mixed with black; pectus, mid and hind legs and ventral surface of abdomen pale brown. Fore wing pale brown irrorated with blackish, the medial area suffused with black; diffused reddish-brown fasciæ in submedian fold and in discal fold beyond the cell; subbasal line black, from costa to submedian fold; antemedial line rather diffused, black defined on inner side by whitish, waved, oblique to submedian fold; orbicular and reniform with indistinct whitish annuli, the former round; in indistinct diffused sinuous black medial line; postmedial line black defined on outer side by whitish, produced to slight streaks on the veins, oblique to vein 5 , then incurved; subterminal line formed by small blackish lunules defined on outer side by whitish, angled outwards at vein $7 ;$ a terminal series of black strix and fine pale line at base of cilia. Hind wing white tinged with reddish brown; the underside with small blackish discoidal spot, indistinct postmedial line with minute black streaks at the veins, and terminal series of black strix.

Hab. N. Nigeria, Minna (Macfie), 5 ð, 1 type. Exp. $26 \mathrm{~mm}$.

\section{5 b. Busseola cuprescens, sp. $\mathrm{n}$.}

శ. Head and thorax cupreous brown mixed with ochreous; antennæ, palpi, and legs brown; tarsi ringed with white; abdomen ochreous suffused with brown. Fore wing ochreous suffused with cupreous brown; an antemedial dark point on vein 1 ; some dark scales beyond lower angle of cell; a slight oblique dark subterminal shade arising from termen below apex. Hind wing white with a very faint brownish tinge; the underside with the costal area more strongly tinged with brown. $20 \mathrm{~mm}$.

Hab. N. Nigeria, Minna (Macfie), 2 type. Exp. 4675 c. Busseola holoscota, sp. n.

ð. Head, thorax, and abdomen dark brown slightly mixed with grey; tarsi ringed with white. Fore wing dark brown slightly mixed with grey; a very slight black streak in medial part of submedian fold; some reddish at base of inner margin; a white point at lower angle of cell with a few black scales round it. Hind wing dark brown; cilia grey-brown; the underside greyish brown.

Hab. N. Nigeria, Minna (Macfie), 2 dype. Exp. $22 \mathrm{~mm}$. 
$4675 d$. Busseola rufidorsata, sp. n.

․ Head, thorax, and abdomen dark greyish brown; pectus, legs, and ventral surface of abdomen pale reddish brown, the tarsi fuscous ringed with white. Fore wing dark greyish brown, the area below submedian fold reddish brown; an indistinct reddish-brown streak in discal fold from middle of cell to well beyond the cell where it is met by an oblique reddish brown fascia from apex. Hind wing greyish brown; the underside whitish tinged with brown.

Hab. N. Nigeria, Minna (Macfie), 1 q type. Exp. $30 \mathrm{~mm}$.

\section{6 a. Acrapex stictisema, sp. n.}

q. Head and thorax grey-brown with a reddish tinge; abdomen grey-brown, the ventral surface tinged with reddish. Fore wing pale grey-brown, the veins of costal and terminal areas with fine grey streaks; a faint fleshcoloured streak in submedian fold; a faint flesh-coloured streak in diseal fold from middle of cell to well beyond the cell, where it is met by a faint oblique flesh-coloured fascia from apex; antemedial blackish points on subcostal and median nervures and vein 1 ; black points in and beyond upper and lower angles of cell; a curved postmedial series of slight black points on veins 7 to 1 ; a terminal series of prominent black points. Hind wing whitish tinged with brown; a fine blackish terminal line from apex to vein 2 ; cilia whitish.

Hab. Dutch N. Guinea, Iwaka R. (Wollaston), 1 q type. Exp. $40 \mathrm{~mm}$.

\section{0 a. Sesamia steniptera, sp. n.}

Fore wing very narrow, the apex produced and the termen oblique.

$\delta$. Head and thorax whitish tinged with grey ; antennæ blackish except towards base; palpi, front of pectus, and fore legs blackish ; abdomen whitish. Fore wing pale fleshpink ; the costal area tinged with grey to beyond middle; the basal inner area pale grey; a faint oblique subterminal grey shade between veins 6 and 2 ; cilia pale grey. Hind wing white.

Hab. Thansvaal, Johannesburg (Cooke), 1 đo type. Exp. $30 \mathrm{~mm}$.

4762 a. Sesamia fuscifrontia, sp. n.

d. Head and thorax ochreous; palpi, frons, and fore legs fuscous brown; mid legs tinged with brown; abdomen 
ochreous whitish. Fore wing ochreous slightly irrorated with brown, more thickly on terminal area except towards tornus; the veins faintly streaked with whitish towards apex. Hind wing oclireous white; the underside with the costal area tinged with brown except towards base.

Hab. Br. E. Africa, N. Kavirondo, Maramas Distr, Ilala (Neave), 1 o type. Exp. $22 \mathrm{~mm}$.

\section{7 a. Sesamia nigritarsis, sp. $n$.}

q. Head and thorax ochreous slightly tinged with rufous; palpi with some brown; fore legs fuscous on inner side; mid and hind tibix with the spurs black except at tips; tarsi black at extremities; abdomen ochreous. Fore wing ochreous slightly tinged with rufous; the median nervure irrorated with black; postmedial black points on veins 6 to 3 ; a terminal series of hlack points from below apex to above vein 2. Hind wing pale ochreous suffused with brown except on costal and tornal areas which are slightly irrorated with fuscous; small terminal blackish spots between veins 7 and 2 . Underside ochreous irrorated with fuscous; fore wing with the disk suffused with fuscous; hind wing with slight blackish streak in middle of cell, discoidal spot, and terminal series of black striæ.

Hab. Br. E. Africa, Aberdare Mts. (Neave), 1 o type. Eap. $50 \mathrm{~mm}$.

4776 a. Conicofrontia scotochroa, sp. n.

q. Head and thorax fuscous brown; abdomen dull reddish brown. Fore wing dull reddish brown, tinged with fuscous; a slight dark terminal line and fine pale line at base of cilia. Hind wing white tinged with reddish brown.

Hab. Transvanl, Pretoria (Distant), 1 o type. Exp. $40 \mathrm{~mm}$.

Genus Apsaranycta, nov.

Type, A. bryophilina.

Proboscis aborted, minute; palpi porrect, hardly extending as far as the frons which has a large pointed conical prominence; eyes large, round; antennæ of female bipectinated with short branches, the apical half ciliated; thorax clothed almost entirely with scales and without crests; tibiæ fringed with rather long hair; abdomen with dorsal crest at base only. Fore wing with the apex rounded, the ternen evenly curved and not crenulate; veins 3 and 5 from near angle of ccll; 6 from upper angle; 9 from 10. 
anastomosing with 8 to form the areole; 11 from cell. Hind wing with veins 3,4 from angle of cell ; 5 obsolescent from just below middle of discocellulars ; 6, 7 from upper angle; 8 anastomosing with the cell near base only.

\section{2 a. Apsaranycta bryophilina, sp. n.}

q. Head and thorax glossy white; palpi, lower part of frons, antennæ, and tegulæ black; pro-, meso-, and metathorax with paired black spits; legs black-brown and white; abdomen black, the anal tuft white, the ventral surface black-brown and white. Fore wing glossy white; an oblique black bar from base of costa to vein 1 ; an oblique antemedial black spot from costa and four obliquely incurved spots from middle of cell to inner margin, with spots beyond them below the cell and above vein 1 ; a black spot at middle of costa and inverted $V$-shaped mark on inner margin; a black annulus in cell towards extremity conjoined to a triangular spot from costa and a spot in lower extremity of cell; two points beyond lower angle of cell and an oblique wared line from lower angle to submedian fold; a postmedial spot on costa, series of five spots between vein 6 and submedian fold angled outwards at vein 4 , and spot on inner margin ; a subterminal series of spots, excurved at middle, then incurved, a triangular patch beyond it from costa with white point at costa, a spot below vein 7 , and irregular fascia at vein 2 from it to termen; irregular spots before termen below apex and at middle, and a series of small spots on termen and cilia. Hind wing black-brown, the cilia white mixed with black-brown. Underside of fore wing suffused with black; hind wing blackish with some white defining a discoidal spot, postmedial curved series of whitish marks, and some whitish marks on termen from discal fold to tornus. $40 \mathrm{~mm}$.

Hab. Вомвау, Anshi (T.R. Bell), 1 क type. Exp.

\section{8 a. Callyna contrastans, sp. $n$.}

+ . Head and thorax fuscous black; pectus white ; tibire and tarsi banded with orange; abdomen fuscous tinged with blue-grey. Fore wing black; an orange subbasal bar from costa to submedian fold, an antemedial bar from costa to middle of cell, a medial bar from costa to subcostal nervure, two points on postmedial part of costa, and a spot at apex. Hind wing with the basal and inner areas pure white, the rest of wing fuscous black. Underside of fore wing with 
some whitish at base, two postmedial points on costa and the apical spot yellow, a terminal series of minute white points; hind wing with the outer edge of the white area irregular. 44. $\mathrm{mm}$.

Hab. Gold Coast, Bibianaha (Spurrell), 1 б type. Exp.

\section{ERASTRIANAT.}

5003 b. Acidaliodes melasticta, sp. n.

9. Head, thorax, and abdomen pale grey-brown; the back of head with black point; palpi with some black at side of second joint ; fore legs suffused with blackish, the mid and hind legs and ventral surface of abdomen brownish white. Fore wing pale grey-brown; a black point at base of median nervure ; subbasal black points below costa and cell; traces of an antemedial line with four black points on it; a black point in middle of cell; a curved medial series of five black points; black points at angles of cell with a slight blackish mark above it on costa ; ubliquely placed black points on and below costa; traces of a pale subterminal line with black points on its outer edge, excurved below vein 7 and at middle; a fine waved black terminal line with series of prominent black puints on it. Hind wing pale grey-brown; a subbasal black point above inner margin; an oblique brownish medial line strongly irrorated with black scales; an indistinct brownish subterminal line with series of small black spots on it, angled inwards at discal fold, then oblique; a fine waved black terminal line with series of promiuent black points on it; cilia irrorated with black-scales; the underside white slightly tinged with brown.

Hab. Dutch N. Gujnea, Mimika R. (Wollaston), $1 q$ type. Exp. $16 \mathrm{~mm}$.

5004a. Acidaliodes strenualis, sp. n.

9. Head, thorax, and abdomen pale red-brown; pectus whitish. Fore wing pale red-brown mixed with some whitish and with slight dark irroration; a deeper red-brown medial shade from discal fold to inner margin; a slight blackish streak in discal fold beyond the cell; postmedial line whitish, slightly defined on inner side by blackish towards costa, very oblique from middle of costa to discal fold towards termen, then inwardly oblique, some darker brown on its onter side towards inner margin and some black striæ beyond it from costa; a series of short black subterminal 
streaks defined on outer side by whitish from costa to vein 4 , followed by a fine whitish line from discal fold to inner margin. Hind wing pale red-brown irrorated with a few black scales; postmedial line whitish, excurved below costa; a whitish line before termen; the underside whitish tinged with brown, a black discoidal point, medial and postmedial brown lines and a brown subterminal shade, a terminal series of minute dark spots. $16 \mathrm{~mm}$.

Hab. Bonneo, Sarawak (Wallace), 1 q type. Exp.

\section{0 a. Aræoptera ecphaa, sp. n.}

q. Head and thorax white mixed with some brown; antennæ ringed with brown; fore legs blackish; abdomen white dorsally suffused with blackish. Fore wing whitish suffused with red-brown, the costa with alternating minute black and whitish streaks; slight blackish points in and bey ond lower angle of cell; subterminal line white defined on outer side by blackish suffusion, oblique from apex to vein 5, excurved at middle; a terminal series of black points. Hind wing whitish suffused and irrorated with black; cilia whitish mixed with brown; the underside whitish tinged with fuscous; obscure diflused oblique antemedial and subterminal blackish shades, a terminal series of blackish points.

$10 \mathrm{~mm}$.

Hab. S. Nigerta, Baro (Simpson), 1 q type. Exp.

\section{8a. Enispa favitincta, sp. n.}

б. Head and thorax brown mixed with grey; pectus and legs white tinged with brown; abdomen white tinged with brown, the basal segment rufous. Fore wing yellowish white, the basal half and costal area to near apex suffused with fuscous brown; some purplish at base and some rufous below the cell before middle and in and beyond end of cell ; a small blackish discoidal spot; postmedial line represented by a yellowish lunule beyond the cell and slight lunule below vein 4 ; subterminal line yellowish white, defined on inner side by slight lunulate fuscous brown marks and on outer side by lunulate fuscous brown marks from costa to vein 3. Hind wing fuscous brown irrorated with silvery scales, the termen pale yellow; cilia yellowish mixed with brown. Underside of fore wing white, tinged with fuscous brown to submedian fold, its outer edge running obliquely 
from apex; bind wing white with a faint fuscous tinge except on marginal areas. $16 \mathrm{~mm}$.

Hab. Gold Coast, Kumasi (Whiteside), 1 o type. Exp.

\section{8 a. Eublemma porphyrescens, sp. n.}

$\delta$. Head and tegulæ fuscous brown mixed with grey; thorax and abdomen pale purplish brown; pectus and legs whitish, the fore tibiæ blackish, the tarsi black ringed with white; abdomen with the anal tuft blackish, the ventral surface whitish. Fore wing pale purple slightly irrorated with brown; subbasal line represented by a black spot on costa and point in cell ; antemedial line reddish brown with a black spot on costa, waved; a slight reddish-brown spot in middle of cell ; the reniform defined by rather diffused reddish brown, narrow; medial line with black spot at costa, slight and excurved beyond the cell and waved below the cell ; postmedial line reddish brown with a black spot at costa, oblique to vein 6 and incurved below vein 4, some pale points beyond it on costa ; subterminal line black defined on inner side by pale rufous and with blackish suffusion beyond it, somewhat dentate, angled outwards below vein 7 and at middle and inwards at discal fold; a terminal series of black striæ ; cilia pale rufous at base, fuscous at tips. Hind wing whitish, the area along vein 1 except at base and between veins 4 and 2 irrorated with black and rufous; an indistinct minutely dentate subterminal line, the area beyond it tinged with fuscous except towards tornus; a black terminal line; cilia rufous mixed with black, the underside white, the costal and terminal areas faintly tinged with rufous and irrorated with brown.

Hab. N. Nigeria, Zungeru (Macfie), 1 to type. Exp. $16 \mathrm{~mm}$.

\section{4 a. Eublemma postrufa, sp. n.}

$\delta$. Head and thorax grey mixed with fuscous brown; pectus and legs pale rufous, the fore and mid tibiæ fuscous, the tarsi black ringed with white; abdomen fuscous brown, the ventral surface pale rufous. Fore wing pale purple slightly irrorated with red-brown, the basal area with a greyish tinge, subbasal black spots on costa and in cell; antemedial line black, expanding into a spot on costa, rather inwardly oblique, waved; some red-brown scales in middle of cell; reniform defined by rather diffused redbrown, narrow; medial line red-brown with black spot at 


\section{Genera and Species of Noctuida.}

costa, slight und excurved beyond the cell, waved below it; postmedial line black slightly defined on outer side by grey, expanding into a spot at costa, oblique to vein 6 and below vein 4 , incurved at submedian fold; the postmedial area rufous with some blackish on costal area, at middle, and above inner margin; subterminal line black, dentate, the area beyond it rufous with blackish suffusion at apex, and above middle and tornus; a terminal series of black striæ; cilia rufous mixed with blackish. Hind wing with the basal half white with black suffusion between veins 4 and 2 and along vein 1 ; a black postmedial line obsolete towards costa and at submedian fold; the terminal half rufous; a dentate subterminal line, fuscous on costal half, black on inner half; a terminal series of black striæ; cilia rufous mixed with blackish; the underside whitish, the costal and terminal areas slightly tinged with rufous and irrorated with brown.

Hab. Br. E. Arrica, Nairobi (Anderson), 1 б’ type. Exp. $20 \mathrm{~mm}$.

\section{6 a. Eublemma atrimedia, sp. n.}

. Head, thorax, and abdomen purplish grey irrorated with black; pectus, legs, and ventral surface of abdomen pale grey, the fore and mid tibix suffused with black, the tarsi blackish with pale rings. Fore wing purplish grey irrorated with black, the medial area suffused with black; subbasal line black, slightly excurved below costa and ending at submedian fold; antemedial line black, sinuous; expanding into a small spot at costa; a small black spot in middle of cell and discoidal bar; medial line black, expanding into a small spot at costa, excurved beyond the cell, and waved below it; postmedial line black, expanding into a small spot at costa, bent outwards below costa, incurved at discal fold and below vein 4 ; subterminal line black slightly defined on inner side by grey, forming small dentate marks to discal fold, then waved. Hind wing purplish grey irrorated with fuscous; some black irroration along vein 1 except towards base and obscure blackish medial postmedial and subterminal bars at vein 2 .

Hab. N. Nigeria, Zungeru (Simpson), 1 б type. Exp. 24 $\mathrm{mm}$.

\section{8 a. Eublemma mesozona, sp. n.}

$\delta$. Head and tegulæ yellow, the latter brownish towards tijs which are white; palpi black above; antennæ blackish; thorax creamy white; legs tinged with brown, the fore legs 
blackish in front; abdomen white tinged with brown. Fore wing creamy white; the costal edge black towards base; a small subbasal black spot in cell; antemedial line absent; medial line black, slightly excurved below costa, angled outwards in end of cell, then sinuous, closely approximated to the postmedial line and with the area between them brown; a black spot at lower angle of cell, some creamy white on discocellulars and sometimes a black point at upper angle of cell; postmedial line blackish, angled inwards at upper angle of cell, excurved just beyond the cell, then sinuous ; two minute black streaks with whitish between on costa at origin of the subterminal line, which is brown, angled outwards at vein 6 , and excurved at middle and below the submedian fold; the termen tinged with brown and with a terminal series of black stria; eilia ochreous brown. Hind wing creamy white tinged with brown; a terminal series of minute black lunules from apex to submedian fold: the underside with traces of curved brown subterminal line.

q. Fore wing wholly tinged with brown and irrorated with a few brown scales, the ante- and postmedial lines browner and rather further apart; bind wing strongly tinged with brown.

Hab. Gold Const, Bibianaha (Spurrell), 4 ot, 1 type. Exp. $24 \mathrm{~mm}$.

\section{4a. Eublemma albivia, sp. n.}

$\delta$. Head and thorax rufous; antennæ dark brown; pectus and legs whitish irrorated with brown; abdomen reddish brown mixed with whitish and with whitish segmental lines. Fore wing red-brown pencilled with whitish and darker brown, the costal area whitish to beyond middle; antemedial line whitish, excurved below costa, then obliquely curved; a slight dark discoidal spot; medial line red-brown defined on outer side by white, angled outwards at vein 6 to below apex, then very oblique, met at vein 6 by an oblique white streak from apex; postmedial line slight black and very oblique to the apical streak, then white, minutely waved and with series of black points on it, closely approximated to the medial line and incurved below vein 4, some white points beyond it on costa ; subterminal line slight, whitish, somewhat waved, excurved below vein 7 and at middle, angled inwards at vein 2 and ending at tornus; the terminal area tinged with blackish; a fine black terminal line and white line at base of cilia which have two waved brown lines through them. Hind wing red-brown pencilled 
with whitish and darker brown, a rufous patch beyond the cell; an oblique white medial line ; postmedial line slight, whitish, minutely dentate and with minute black streaks at the veins; traces of a pale minutely waved subterminal line; a dark terminal line and white line at base of cilia which have waved brown lines through them; the underside white irrorated with brown, an indistinct brown line from lower angle of cell to inner margin, and traces of a waved subterminal line.

Hab. Gond. Cossr, Kumasi (Sanders), 1 type. Exp. $22 \mathrm{~mm}$.

5264a. Eublemma melabasis, sp. n.

๙. Hęad and tegulæ brownish white : thorax pale grey with some fuscous on outer edge of patagia and extremity of metathorax; pectus and legs whitish, the fore and mid tibiæ fuscous, the tarsi black ringed with white ; abdomen brownish white. Fore wing white very finely and thickly striated with brown; the antemedial area suffused with black, bounded by the inwardly oblique black antemedial line; a small diffused black discoidal annulus, with a black point above it on costa; postmedial line black and very oblique from costa to near termen above vein 4 , then hardly traceable and incurved, two minute black streaks beyond it on costa ; an oblique black streak from apex to the postmedial line, diffused below and angled outwards at vein 7 ; some black points before inner half of termen; a brownish terminal line. Hind wing white irrorated with brown; some black points before termen towards tornus; the underside white slightly irrorated with brown.

Hab. N. Nigeria, Zungeru (Macfie), 1 o type. Exp. $18 \mathrm{~mm}$.

\section{Genus Lophocryptis, nov.}

Type, L. argyrophora.

Proboscis fully developed; palpi upturned, slender, the second joint reaching to about middle of frons, the third moderete; frons smooth ; eyes large, round; antennx of female ciliated; thorax clothed entirely with scales and without crests; tibiæ slightly fringed with hair; abdomen without crests. Fore wing with the apex rectangular, the termen slightly excised below apex, excurved at vein 4, then oblique; veins 3 and 5 from near angle of cell ; 6 from upper angle; 7 shortly stalked with 8,$9 ; 10,11$ from cell. Hind wing with a large tuft of elongate scales in end of cell on upperside; veins 3,4 from angle of cell ; 5 nearly fully 
developed from well above angle; 6,7 from upper angle; 8 anastomosing with the cell near base only.

\section{0 a. Lophocryptis argyrophora, sp. n.}

․ Head, thorax, and abdomen creamy white; antennæ blackish. Fore wing creamy white irrorated with a few black and silver scales; antemedial line faint, ochreous brown, excurved below costa, incurved at median nervure and excurved below the cell, an oblique ochreous-brown striga beyond it from costa; an ochreous-brown discoidal bar with silver scales on the discocellulars, an oblique ochreous-brown striga above it from costa; a black and silver postmedial point below vein 5 ; postmedial line faint, red-brown, obliquely curved from costa beyond middle to tornus, a rufous tinge before it at middle and the area beyond it suffused with rufous; three black points on costa towards apex, and a silver patch below costa; a rather maculate silver line from below costa towards apex to termen at vein 4 , and some silver scales below vein 4 before termen; a series of black stria before termen from below vein 7 to below 3 and some black on termen from vein 6 to below vein 4 where there are two small black spots on the cilia. Hind wing creamy white, the inner area irrorated with a few black scales; a series of black points before termen and a silver terminal line; the underside white irrorated with a few black scales, a series of black points before termen from apex to submedian fold.

Hab. Gold Coast, Bibianaha (Spurrell), 1 q type. Exp. $20 \mathrm{~mm}$.

Type, L. melanephra.

Genus Lamprolopina, nov.

Proboscis fully developed ; palpi upturned, the second joint reaching to about vertex of head and moderately scaled, the third moderate; frons smooth ; eyes large, round; antennæ of male ciliated ; thorax clothed almost entirely with scales and without crests; tibiæ moderately fringed with hair ; abdomen with dorsal series of crests except on two basal segments. Fore wing with the apex rounded, the termen evenly curved and not crenulate; veins 3 and 5 from near angle of cell; 6 from upper angle; 7, 8, 9 stalked ; 10, 11 from cell. Hind wing with veims 3,4 from angle of cell ; 5 nearly fully developed from just below middle of discocellulars ; 6, 7 from upper angle; 8 anastomosing with the cell near base only.

In key differs from Xanthograpta and Parangitia in 
having a dorsal series of crests except on two basal segments.

\section{5 a. Lamprolopha melanephra, sp. n.}

Head, thorax, and abdomen ochreous tinged with greybrown, the dorsum of thorax with fuscous ; antennæ blackish except above towards base; palpi black, the third joint ochreous; pectus arid legs black, the tarsi ringed with white; abdomen with the crests silvery placed on black spots which are large on third to fifth segments, small on sixth and seventh, and paired on eighth segment, the ventral surface irrorated with black. Fore wing ochreous tinged with grey-brown and irrorated with some black scales especially on terminal area; a short black streak on costa before the very indistinct waved brown antemedial line; a more distinct waved medial line with oblique black striga from costa; a small black discoidal lunule; postmedial line double, blackish filled in with whitish, the outer line stronger, oblique to vein 6, excurved between veins 4 and 2 and incurved in submedian interspace, some pale points with minute black streaks between them beyond it on costa; subterminal line greyish ochreous, excurved at vein 7 and middle ; a punctiform black terminal line; cilia with some blackish spots at middle. Hind wing ochreous tinged with grey-brown, the terminal area suffused with reddish brown; an oblique black discoidal bar; postmedial line black, minutely waved, incurved at discal and submedian folds ; an indistinct pale sinuous subterminal line; a rather punctiform black terminal line; cilia with a fine pale line at base and some blackish spots at middle; the underside whitish suffused with black, the lines blackish.

Hab. Goud Const, Bibianaha (Spurrell)), 4 o, 1 q type, Kumasi (Sanders), 20 . Exp. $16 \mathrm{~mm}$.

\section{Genus Epicerynea, nov.}

Type, E. goniosema.

Proboscis aborted, minute; palpi upturned, the second joint reaching to well above vertex of head and fringed with hair behind towards extremity, the third long; frous smooth; eyes large, round; antennæ of male with long cilia; thorax clothed almost entirely with scales and without crests; tibiæ slightly fringed with hair; abdomen without crests. Fore wing with the apex rectangular, the termen oblique towards tornus; vein 3 from before angle of cell; 4, 5 from angle; 6 from below upper angle; 7, 8, 9, 10 stalked; 
11 from cell. Hind wing with veins 3,4 from angle of cell ; 5 nearly fully developed from well above angle; 6,7 from upper angle ; 8 anastomosing with the cell near base only.

\section{1 a. Epicerynea goniosema, sp. n.}

$\delta$. Head, thorax, and abdomen creamy white ; antennæ brownish : palpi with the second joint brown behind, the third with black ring near tip ; fore legs dark brown. Fore wing creamy white faintly tinged in parts with pink; the costal edge brown towards hase; an L-shaped black-brown discoidal mark with oblique black-brown wedge-shaped mark above it from costa ; postmedial line faint, brownish defined on outer side by white and with a slight black-brown mark at costa, oblique to vein 5 , then erect, a wedgeshaped black-brown patch beyond it on costal area with some pale points on costa; a series of black-brown strixe before termen and a series of slight strix on termen; cilia with some brown at tips at apex and middle. Hing wing creamy white tinged with pink except at base; a red-brown shade with some black scales on it from lower angle of cell to inner margin; postmedial line pale red-brown defined on outer side by white, curved; a series of red-brown points before termen and a termiual series of slight strix. Underside of fore wing suffused and irrorated with brown especially on costal area.

Hab. Gold Coast, Kumasi (Sanders), 1 б type. Exp. $16 \mathrm{~mm}$.

\section{2 a. Cerynea digonia, sp. n.}

9. Head yellow with a white patch between antennæ, which are white towards base ; thorax purple-red, the basal half of tegulæ yellow; pectus and legs yellow; abdomen purple-red, the anal tuft orange-yellow, the base of ventral surface yellowish. Fore wing purple-red irrorated with a few silvery scales; a triangular antemedial yellow patch from costa to just below the cell and a triangular postmedial patch from costa to discal fold ; the apex yellow, the termen with yellow mixed, the cilia yellow. Hind wing purple-red irrorated with a few silvery scales; traces of a pale curved postmedial line; the termen with yellow mixed; cilia yellow; the underside pale yellowish, a small brownish discoidal spot, indistinct oblique postmedial line, and broad subterminal shade.

Hab. N. Nrgeria, Minna (Macfie), 1 q type. Exp. $16 \mathrm{~mm}$. 


\section{Genus Chrysozonata, nov.}

\section{Type, Crysocraspeda flavaria.}

Proboscis aborted, small; palpi upturned, slender, the second joint reaching to middle of frons, the third short; frons smooth ; antennæ of female ciliated ; thorax clothed almost entirely with scales and withont crests; tibiae slightly fringed with hair; abdomen without crests. Fore wing with the apex rounded, the termen evenly curved and not crenulate; veins 3 and 5 from near angle of cell; 6 from upper angle ; 9 and 10 anastomosing with 8 and 11 anastomosing with 10 to form a double areole. Hind wings with veins 3, 4 from angle of cell ; 5 nearly fully developed from just below middle of discocellulars ; 6,7 from upper angle; 8 anastomosing with the cell near base only.

\section{6 c. Chrysozonata purpurascens, sp. $n$.}

9. Head and thorax purplish grey mixed with blackish and some silvery scales; abdomen purplish grey with a flesh-pink tinge towards base, the crests black with silvery scales mixed; palpi, pectus, legs, and ventral surface of abdomen whitish suffused with brown. Fore wing with the base and costal area to near apex purple-grey irrorated with blackish and some silvery scales, the inner half just before the antemedial line and on medial area flesh-pink, the terminal area yellow; antemedial line yellow defined on each side by blackish on the dark area, angled outwards below costa, then oblique and slightly angled outwards in cell and submedian fold; two oblique dark striæ from middle of costa; postmedial line yellow defined on each side by blackish on the dark area and with some flesh-pink suffusion before and beyond it, forming a yellow lunule at discal fold and angled outrards at veins 4,3 , then dark brown, bent inwards to near origin of vein 2 and incurved to inner margin, some dark suffusion beyond it between veins 5 and 3 extending to near termen; a series of dark points just before termen. Hind wing purplish grey suffused with flesh-pink and with some dark brown irroration, the terminal area yellow; rather diffused dark antemedial, medial, and postmedial curved lines, and a dark discoidal striga ; a series of dark points just before termen. Underside of both wings purplish grey to the postmedial line, the terminal area yellowish white.

Hab. Mashonaland (Dobbie), 1 g type. Exp. $24 \mathrm{~mm}$.

[To be continued.] 